Identity-machines.

The Nationalism of Hungarian Operetta between the Two World Wars

\author{
Magdolna Jákfalvi \\ Univerza za gledališče in film, Budimpešta \\ University of Theatre and Film Arts, Budapest
}

Maybe it was due to the bitterness of Trianon, maybe due to our vulnerability, but in that moment, this unassuming little fairytale became an incredible success. ${ }^{1}$

The identity of a nation reveals itself in various manifestations. Brief lines of poetry and music are capable of transmitting the national idea, of rendering it quotable. Landscapes sometimes gain sentimental meaning, and musical motifs call forth personal emotions from a shared national memory. Music is especially well-suited to impressing the (current or former) unity of the community upon the individual, as the structure of national anthems written in the $19^{\text {th }}$ century still demonstrates.

From the beginning of the $2 \mathrm{O}^{\text {th }}$ century, Hungarian national identity has been strongly shaped by the operetta genre. More people grow up listening to the music of Lehár and Kálmán, than to the music of Bartók. It is nevertheless surprising that the most widely known musical manifestation of love-for-the-homeland is derived from the finale of what might very well be the least well-known Hungarian operetta. Only one song is remembered of the 1922 Kulinyi-Vincze operetta titled The Hamburg Bride, the one that became a melodic essence of national awakening. In my paper I examine the wanderings of a melody torn from its musical and theatrical context, I demonstrate how a banally simple, boilerplate tune by a composer and a librettist of Jewish origin became an irredentist anthem, then an outlawed 
lieu de memoire. Considering the context of the operetta at the time of its premiere as well as its entire history of effect, I focus on the elements of theatrical practice in order to transcend the historical analysis of memory politics, and attain the operetta genre's own method of processing national trauma after the First World War.

The world of the operetta is obscured in a curious mist of remembrance. Whoever steps into this mist is frozen in time, lost in space, with all their explanatory context melting off them: this is the world of the impossible. The hegemonic political memory did not adopt the operetta into Hungarian cultural history, and this markedly banal medium is part of a history lost to embarrassment. The operetta's burlesque bumbling and grandiose pronouncements, its silly, parodic aristocrats and dashing idealised nobility do not belong to the history of the nation. Nevertheless, communal memory recalls the world of interwar musical theatre, a world revealed through operetta, as its own past.

We know that Austro-Hungarian operetta habitually avoided the events of historical reality, choosing instead, for example, to sing about the wedding of a Romanian nightclub singer to a Hungarian duke in 1916 Vienna, in the middle of the First World War. While this particular example is brilliant, the many imitations and copycats that were created offer few with enough melody or merit to still be recalled by the theatrical memory-machine. However, a single song from a completely forgotten musical exposes a pathway of remembrance, lifting this phenomenon from the discourse on musical and theatre history, and shifting it towards the sociology of national identity and the process of its development.

\section{What is this operetta?}

The Hamburg Bride premiered in 1922, co-authored by Zsigmond Vincze, the conductor of one of Budapest's leading musical theatres (Király Theatre) and Ernő Kulinyi, theatre critic. The operetta builds on strong musical foundations, in the post-WW1 rejuvenation of the theatre scene where dozens of entertainers promoted well-crafted if derivative imitations of Kálmán and Lehár, with The Hamburg Bride being one of these.

The libretto follows well-known tropes from the silver age of Austro-Hungarian operetta: Count Bálint Choltay of Cholta, the Don Juan of the Baden-Baden spa, having conquered all available women, decides to ensnare a girl named Lotti Werner. Lotti is apparently a shopkeeper's daughter, with especially lovely ankles, and the countesses on holiday also find 
her rather attractive. The libretto reveals more about her father, Hermann Werner, a Hamburg merchant who keeps his legendary wealth secret while on holiday.

After the first scene, it becomes clear that the authors relied so heavily on their audience's knowledge of operetta clichés, and thus did not bother to explain the causes, connections and motivations that form the plot. They made a mockery of historical accuracy, setting the work in 1780, even though Baden-Baden only became a fashionable spa in the mid-18oos, and ignored how impossible it would be, in that warlike, revolutionary era, to cross the seven hundred kilometres between Hamburg and the spa town by stagecoach. The context of geographical, technical impossibility connotes the sociologically impossible. The impossible romance blossoms at first sight between the impoverished Hungarian count and the rich Polish-Jewish girl, as the rich pretends to be poor and the poor pretends to be rich. Trying to hide this reality, Choltay borrows his own lost castle back from his cousin. He successfully keeps up appearances, presenting himself as the lord of his own estate, and while the bon vivant/male lead moves into the role of an intriguer/con man, in the post-war chaos this is less a case of poor writing and more of a familiar situation.

The libretto is based on this impossible situation, and, unbelievably, the count's grandiose lie is never revealed. The Jewish merchant girl from Hamburg becomes a Hungarian countess, probably without ever discovering the truth. Of course the librettists somehow paper over the conflicts in time for the finale, the villainous aunt is appeased, and Choltay recovers ownership of the castle: the Hungarian count's lie is perfectly suited to the banality and impossibility of operetta.

The operetta's framework of impossible situations is held together by a single melody, heard for the first time in the finale of the first act. Musically speaking, the melody is a softened Verbunkos (military dance), while lyrically it is more of an anthem, since it turns away from the experience of existential and emotional impossibility, and towards an idealised reality of Hungary, a faraway land of beauty and happiness. The audience is confronted with a world that is idealised, yet declared to be real, combining the experience of yearning with the pathos of remembrance. For the 1922 audience, this vision of Hungary was just a distant daydream, as it also is for Choltay in 1780. As the Trianon Treaty ended the First World War and redefined the borders of the former Austro-Hungarian Monarchy, the Hungary that Choltay yearns for no longer exists. The name of the Choltay 
estate, Bodrogremete (Bodrog county + hermit) is naturally fictional, but Bodrog county actually exists, and following the Trianon Treaty much of it was detached from Hungary to became part of Czechoslovakia.

A mediocre operetta's finale gained disproportionate popularity in a complex geopolitical situation that made the impossible world of the work seem realistic by comparison. Since the libretto does not make it clear whether the male lead is yearning for his squandered wealth, for the idea of a grand past, or for the fulfilment of his romantic love, the lyrics utilise the aesthetic and causal impossibility of the operetta genre, and express a yearning for something non-existent, just as the Hungary of the 1780 s was by 1922 .

\section{Where is Hungary?}

The Hamburg merchant on holiday in Baden-Baden does not understand where exactly count Choltay invited his daughter: "/in slightly broken Hungarian/ Hungary? Where is Hungary? Does beautiful Hungary still exist for real? The land of hussars? You saw it with your own two eyes?"

The question invited an unexpectedly wide array of interpretations in 1922, and the redrawing of national borders turns this playful, meaningless operetta banter into a question of national identity politics. Discussion of loss and wartime trauma spilled over from increasingly numerous irredentist publications, and found a peaceful medium in operetta, a popular genre that reacted rapidly to current events. "Where is Hungary" is merely a cue before the finale, and Choltay sings the now-famous number as a response. Here I find it is necessary to quote the first verse and chorus of the song, in order to follow the commingling of the real, but unprocessable geopolitical situation, and the impossible but familiar world of operetta.

Verse

Where a bright wind, a light wind plays along the river Tisa

There live a people, a legendary people, there my homeland lies.

The ancient Carpathians protect the sleep of the faithful chieftain Csaba, Who returns to us, again and again, on the celestial path of stars.

When his trumpet calls, we await his coming. 
Chorus

You are beautiful, you are lovely, Hungary,

lovelier than the whole world,

When I hear music, I see your beautiful glowing face.

We fly there on our magic steeds, where grass, tree, leaf and flower call us!

Where the violin cries, a beautiful lovely country awaits us. ${ }^{3}$

Choltay's castle is in Bodrog county, a corner formed by the River Tisa and the Carpathian Mountains in the north-eastern part of pre-Trianon Hungary. Bodrogköz is an ethnically complex borderland region, largely inhabited by Hungarians, alongside Ukrainians and Romanians, in a centuries-old pattern of coexistence. This ethnically diverse region appears in a completely different light on the mental map ${ }^{4}$ of the Hungarian community, not only in terms of its ethnic composition, but also in terms of its geography. This mental map focuses on the perception and experience of space within the relation of man and space, 5 and this is how Bodrogköz becomes a lush green land, almost an Arcadia, inhabited solely by Hungarians. This exuberant natural power, this lovely greenery is an image born of emotional remembrance, not of reality, as Bodrogköz is well-known to be the driest region of the Carpathian basin, with the lowest levels of annual rainfall, a place where plant life is threatened both by drought and an early frost. But at the time of the operetta's premiere it was also common knowledge that Bodrogköz was one of the first areas settled by the early invading Hungarians, that one of the troops of the legendary founding chieftain Árpád rested here in 903. Since the event was recorded in Gesta Hungarorum, one of the nation's earliest chronicles, ${ }^{6}$ it became a lasting element of Hungarian identity. Choltay's castle therefore stands on the lands of the conquering Magyar tribes, and the Choltay estate is described as an Arcadian image of the country as it once was.

The lyrics reinforce this mental landscape when they evoke two contrasting auditory memories, placing the mournful cry of the violin next to the triumphant call of the trumpet.

If we analyse the lyrics and their dramatic context, we arrive at a historically impossible moment: conquering Hungarians stand next to the Ibid.

4 Kevin Lynch, The image of the city (Ann Arbor: MIT, 1960), 8.

Róbert Keményfi, “Az 'etnikai táj’ kultúrnemzeti mítosza,” Regio 2, no. 4 (2002): 105. Edit Tamás, “A Bodrogköz tájmonográfiája,” Zempléni múzsa 9, no. 35 (2009): 87-90. 
lush, green River Tisa with the Transylvanian folk hero, Prince Csaba, doing who knows what? Presumably just gazing at the landscape, themselves becoming part of a national tableau. The lack of a verb, of an action reminds us that we are analysing an operetta, not a political manifesto. The lyrics do not want, or call for, anything, they merely list the not-yet-irredentist, merely identity-forming tropes of 1922 popular discourse: the pride of a thousand-year-old nation, the richness of nature, the power of beauty and bravery. This is the landscape of having arrived, this is Hungary as it exists in operetta.

\section{What was the premiere like?}

In order to analyse the role of a single operetta number in memory politics, it is relevant to discuss the performance's context in theatre history. The Hamburg Bride premiered on January 31, 1922 in one of the largest and strongest establishments on the Budapest musical theatre scene, the Városi Theatre. The composer, Zsigmond Vincze, being the conductor of a rival institution, Király Theatre, knew the Városi's ensemble well. It was routine practice in theatrical life to create some buzz in the press in the months leading up to the premiere. From 1921 on there are weekly, then closer to the premiere, almost daily news stories ${ }^{8}$ in the papers about which actors accepted a role in the show and who refused it. The diva Sári Petress is the prima donna/female lead, Imre Palló, a singer from the Opera plays the male lead, and the most notable theatrical publication, Színházi Élet (Theatrical Life) interviewed the entire cast. ${ }^{\text {? }}$

The theatrical promotion of the 1920 s deliberately blurred the line between events in reality and on stage, between the roles and personal lives of the stars. Headlines, and even the articles themselves presented the onstage lives of prima donnas in the framework of reality. This makes the articles somewhat obnoxious, but nevertheless furthers the popular identification of the actor with the role. In our analysis, this is most noticeable when the cast changes prima donnas. In 1923, when Petress leaves and a new Lotti is found to replace her, the next run of the show advertises the second actress, Kolbay, as an object to be bought and sold: "A new bride arrived from Hamburg. [...] In two brief months, Kolbay was married for the second time

“Hamburg - Budapest!" Színházi Élet 7, no. 5 (1922): 22-3.

$8 \quad$ Uj Budapest, January 18, 1922, 4.

9 “Hat intervju A hamburgi menyasszony-ról," Színházi Élet 7, no. 4 (1922): 18-9. 
last week." The work gained the fawning title of "the most excellent operetta of the season," owing more to the advertising campaign around the premiere, and less to its musical merits. The discourse centres on the fairytale marriage, on obtaining the beloved girl, but this victory is not yet associated with obtaining the country, or more pertinently, regaining it. The operetta's object is a standard romantic seduction, nothing more.

The actors were captured in costumed studio photographs, wearing the sartorial relics of an invented Hungarian past, rococo powdered wigs alongside $16^{\text {th }}$ century fur jackets, creating an impossible, yet familiar operetta milieu. The impression of Hungarianness is derived from military gold braid and floral Kalocsa embroidery, which appears folksy in the Baden-Baden setting, and is not typical of the actual Bodrog region either, meaning that more than anything these images manifest the alienness of Choltay's character. We have no visual documentation of the set used for the premiere, even though the theatre commissioned the most popular, most well-known set designer, the master of the Opera, Jenő Kéméndy, and he apparently "succeeded in creating a very beautiful Hungarian milieu."'

As " the second act takes place back home in Greater Hungary [...] there are lots of opportunities for creating ambiance, using crowd scenes and decorative effects." Further information on the elements of ambiance is written in an (undated) director's copy:

The map of Greater Hungary in muted green tones, but with strong borders. Hovering above, a Hungarian crown lit by many colourful bulbs, held by floating winged angels on the left and right. In the left and right corners two kuruc rebel soldiers with the national flag, in the middle a peasant girl with a sickle hands a sheaf of wheat to a Hungarian peasant, who looks upward leaning on his scythe. ${ }^{13}$

In 1922, highlighting the borders of Greater Hungary on a set backdrop conveyed national anguish over an incomprehensible situation, not irredentist sentiment. The reviews also found the object of the Kéméndy set completely natural, not only because it presented the familiar geographic depiction of the country, but because in 1780, the idea of possessing the entire Carpathian basin belonged just as firmly to the Hungarian identity as

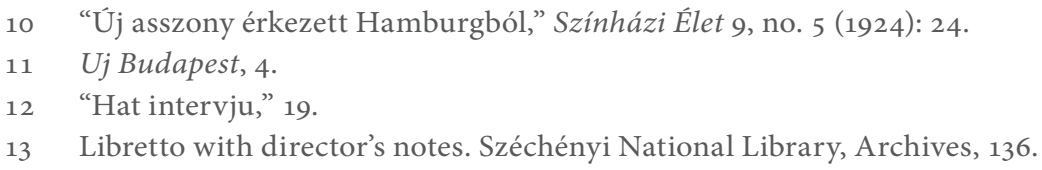


it did in 1922. This possession is not a legal fact in the operetta, but a manifestation of memory politics. ${ }^{14}$

\section{What is the language?}

The operetta is an ideal medium for the emotional evocation and presentday reexperience of the past, because the genre does not recall specific or accurate historical events, it summons the affective waves of memory. The music conveys these emotions with folk melodies, an orchestration based on violins and traditional woodwinds, a Hungarian rhythm, but the language of the utterances leads the present-day reader of the libretto into a curious territory. In 2020, the linguistic register of the libretto is incomprehensible, it is impossible to decipher what this hundred-year-old theatrical language is meant to express, and who is speaking it. Evidently this language does not serve to convey information, but to establish characterisation, so we can only interpret its sound, not its semantics. The language of operetta is Hungarian intermingled with German and Yiddish, intoned in an urban accent. Such a language never really existed, and it is not to be deciphered through the meanings of words and syntax, but through the workings of familial and communal relationships. The father says whatever an overprotective father ought to say, the daughter says whatever a rebellious daughter should, and the socially dynamic cliché is intelligible.

Werner: 'You girl! ... You dared to dance in this club? ... Halt's maul!

... Calm down now! ... Not a word! ... Das gibts nichts! ... I wear the trousers! You'll get what's coming to you. Now go upstairs and pack, we're leaving with the early morning stagecoach! $!^{\text {ts }}$

Operetta uncovers untranslatable clichés, and the clichés cause the language to appear insipid, but this insipidity reveals communal patterns of speech. In 1922, at a rural ball, this is how a father speaks to his young daughter. The literature on operetta considers this linguistic register a facet of the genre's banality, but acknowledges that it is capable of accurately sketching out the communicative network of a community, a framework of reality that everyone in the audience recognises. The realist depiction of

14 Ibid., 135 .

15 Kulinyi and Vincze, Hamburgi menyasszony [Libretto - prompter's copy], 32-3. Rough translation, since the original is untranslatable and largely deliberate gibberish. 
impossible relationships is a key element of operetta performance - especially subsequent, State Socialist operetta performance.

Furthermore the very names of the characters carry traits that approach the sociological make-up of the community through operetta clichés, not national identification. In addition to Count Bálint Choltay of Cholta the landless aristocrat and Hermann Werner the merchant, we encounter the barons Dennewitz and Clausewitz, and ladies Juci and Amália, representing the aristocracy, and Annchen, Trudchen, Klarchen and Marietta, the group of ladies-in-waiting who dance with the spa town's doctor and dance instructor. In these names, we witness the reality of an ethnically diverse monarchy, not the increasingly powerful Hungarian identity prevalent in subsequent analyses.

Linguistic incompetence is the embodiment of humour in the operetta genre, and the incorrect use of language is the source of most jokes. In The Hamburg Bride, Werner's entire role, as the father, is based on his shoddy knowledge of Hungarian.

Werner: And how do they say in Hungarian - to fenster? $?^{26}$ Do they

say, to window?

Juci: Of course not! ... Here they say, to fenster just the same. ${ }^{17}$

Werner: Sie, her Oberstkammerdiener!

Gyurka: I don't speak Jewish, begging your pardon!

Werner: Then I will say it in Hungarian! $!^{18}$

The language evokes the subtle anti-Semitism of the early 1920s, one that does not mention economic stereotypes, and remains an unobtrusive part of general chatter.

Charlotte: ... are you that thirsty?

Kristof: I would drink the entire Red Sea, even though way back when, the whole Lipótváros ${ }^{19}$ used it as a public bath. ${ }^{20}$

16 The verb derived from 'window' means to walk up and down under the window of the beloved woman, in the hope that she will appear there, or at least look out. An informal expression, and as outdated as the wooing method it refers to.

17 Kulinyi and Vincze, Hamburgi menyasszony [Libretto - prompter's copy], 40.

18 Ibid., 45.

19 Translator's note: Lipótváros or Leopold city was considered a stereotypically Jewish central district of Budapest.

20 Ibid., 55. 
It is almost expected that the wealthy merchant from Hamburg be a Polish Jew, and thus the libretto places Jews a little way outside the Hungarian community, with operettic ease. For example, Werner reads the liberal newspaper from Stuttgart, ${ }^{21}$ and from the first act one can suspect that the narrative of his assimilation is what forms the operetta's context in social philosophy. ${ }^{22}$

\section{The process of misinterpretation: the irredentist anthem}

Having examined the thin plot of this operetta, we get ever closer to understanding why this song was the one to become the anthem of intensifying inter-war irredentist endeavours. The operetta was disseminated as better works tended to be in the era: it ran for hundreds of nights, it had a revival in the same theatre where it premiered, its rights were sold to rural theatres, then after five or six years a song separated from its original context, and gained an independent life at musical revues. The Hamburg Bride was considered reasonably successful, but this success owed little to the aesthetic value of the work. We may note a few details around the premiere: the publicity and attention due to the star quality of the cast, the effect of the two film adaptations, and the political position of the author of the novella the libretto was based on. The first two elements of success are generic, but the latter is worth examining, as it exemplifies the well-known possibility of the actor's or writer's life itself becoming a product.

The advertising campaign before the 1922 premiere highlights that the piece has three authors, and the adaptation's source material is given more weight, almost, than the new operetta. They have nothing but praise for Gyula Pekár's novella, The Borrowed Castle. ${ }^{23}$ The position of Pekár, the writer was an early confirmation of irredentist allusions. He had been a state secretary for religion and education, a minister without portfolio for a short while, a member of Parliament for three decades, chaired both the Hungarian Foreign Policy Society and the (far right-wing, ostensibly pan-Turkish nationalist) Turanist Society, and was the chairman of the Petöfi Society, the most important public literary organisation, although he was a rather mediocre writer. Thus his unexceptional writings are inseparable from his political appointments. Pekár died in 1937 but lived long enough to see the irredentist reinterpretation of his most pop-

\footnotetext{
21 Ibid., 17.

22 Ibid., 18.

23 "Hat intervju," 19.
} 
ular work. In the late 1920s, we already see small signs in the press pointing to the reinterpretation of a single song in the operetta, the finale shortened as Lovely Hungary. It was sung in amateur choirs and at trade union events, ${ }^{24}$ and quietly became a sorrowful dirge for the Trianon Treaty, a proud anthem for the secret hope of border revision. As we have seen, the song serves to mentally identify the landscape with the nation, and its simple melody and straightforward meaning makes it easy to learn and sing. At first the chorus of the song was censored by Romanian authorities in Transylvania (replacing Hungary with Wonderland or Fairyland, substitutions which scan reasonably well). ${ }^{25}$ Then when the Second World War border revisions returned Kolozsvár/Cluj Napoca to Hungarian rule, the Hungarian State Opera House paid a visit there, ("the artists of the Budapest Opera House are preparing to leave for Kolozsvár with reverent anticipation" $)^{26}$ and they took Lovely Hungary with them as their standard. The expected and much-discussed ban $^{27}$ by Romania only succeeded in lifting the song into the category of national symbols deserving of protection. As such one of the clear effects of Governor Miklós Horthy's foreign policy (that is, partial border revision) furthered the transformation of a clichéd love song into an irredentist anthem, and the dual character of the song's history of effect is still recognisable.

After the Second World War, the peace treaties and the Soviet occupation-liberation irrevocably confirmed that Hungary was retreating behind the borders set by the Trianon Treaty. The Hamburg Bride, the central motif of which was transformed into an anthem for border revision, was never performed again. But the story of the song itself did not end there, because it was not simply tied to irredentism, and became part of a Hungarian identity composed of complex remembrances. It suffered the fate of songs that are only considered beautiful because of the nostalgia they evoke, and the mode of their performance becomes a symbolic gesture that colours the political communication of the community.

\footnotetext{
24 Anon., "Budai Iparos- és Kereskedőifjak Városmajor utcai kultúraegyesülete," Fővárosi Hírlap 18, no. 44 (1929): 13.

25 József Kötő, “A színházi intézményrendszer Erdélyben a két világháború között,” Korunk 13, no. 4 (2002): 55-64.

26 Ellenzék, 61, no. 253 (1940): 6.

27 Ellenzék, 61, no. 252 (1940): 6.
} 


\section{Bartók Concerto}

The Lovely Hungary song could have disappeared in the four decades of State Socialism, since as an operetta it was mediocre, and as an irredentist song, illegal, but in an extraordinary turn of events no less than Béla Bartók contributed to its survival. The fourth movement of his 1945 concerto clearly, recognisably evokes the first bars of the song, and this has prompted serious and ongoing debates in musical theory and history circles for almost eighty years. First, we must decide who the melody belongs to. Bartók literature refers to Lovely Hungary as a motif of homesickness, which is either "a rhythmically Romanian version of a stereotypically irredentist Hungarian musical reminiscence ${ }^{328}$ or it may be Romanian in its melody. ${ }^{29} \mathrm{~A}$ legendary conductor of the concerto, György Solti, explained that "the pentatonically expressed Hungarian emotions are followed by a fourth movement, the scherzo, jest, often in 5/4 and 5/8 time", and calls it Bulgarian..$^{\circ}$ However, it is possible that the concerto features the exact same notes as the first few bars of Lovely Hungary completely by accident. ${ }^{31}$ It was Hungarians living in emigration during the State Socialist era who found it important to untangle the origins of Bartók's homesickness motif, ${ }^{32}$ and this confirms that it is not solely its status as an irredentist symbol, but its historical relevance to national identity that keeps the song of Kulinyi and Vincze in the memory-machine. ${ }^{33}$

\section{The End of the Austro-Hungarian Monarchy and the End of Austro-Hungarian Operetta}

In the wake of the First World War, Hungary was not yet defined by the trauma of Trianon, the Treaty of Versailles and the brief 1919 period of Soviet rule, but by the fact of spatial nonexistence, nowhereness. With the dis-

28 László Stachó, "Szép vagy, gyönyörű vagy... Magyarország?” Muzsika 49, no. 5 (2006): 36.

29 Ferenc László, "Rumänische Stilelemente in Bartóks Musik - Fakten und Deutungen," Studia Musicologica Academiae Scientiarum Hungaricae 36, no. 3-4 (1995): 413-28, https://doi.org/10.2307/902223.

30 Guillem Calaforra, "Bartók in Budapest Concerto for orchestra Solti," 1 February 2019, YouTube, https://www.youtube.com/watch?v=OQb3VUljpao\&ab_channel=GuillemCalaforra.

32 Béla Bartók, "Concertóról," in Bartók Béla Összegyüjtött írásai I, ed. András Szőllőssy (Budapest: Zeneművészeti, 1966), 790, 437. 
solution of the monarchy, the successor states lost not only their road and railroad networks, but their diplomatic and informative networks as well. ${ }^{34}$ The incomprehensible, opaque nature of the negotiations creating the peace treaty rendered the country invisible, its greatness only retained on its mental map.

The historical arc of The Hamburg Bride's melody incorporates both irredentist aspirations and the memory of the Holocaust. Vincze died in 1936, before the first laws curtailing the rights of Jewish citizens were introduced in Hungary, but Kulinyi lived on. The librettist who penned the legendary lines died in an internment camp in the small Austrian town of Bruch an der Leitha, close to the Slovakian-Hungarian-Austrian border of the former Monarchy.

\section{Bibliography}

Angi, István. “A bartóki iróniáról.” Korunk 23, no. 3 (1981): 87-93.

Anon. "Budai Iparos- és Kereskedőifjak Városmajor utcai kultúraegyesülete." Fővárosi Hírlap 18, no. 44 (1929): 13.

Bartók, Béla. “Concertóról." In Bartók Béla Összegyüjtött írásai I, edited by András Szőllőssy, 435-7. Budapest: Zenemüvészeti, 1966.

Calaforra, Guillem. "Bartók in Budapest Concerto for orchestra Solti." 1 February 2019. YouTube. https://www.youtube.com/ watch? $\mathrm{v}=\mathrm{OQb} 3 \mathrm{~V}$ Uljpao\&ab_channel=GuillemCalaforra.

Carlson, Marvin. The Haunted Stage. Theatre as Memory Machine. Ann Arbor: MIT, 2003.

Ellenzék, 61, no. 252 (1940): 6.

Ellenzék, 61, no. 253 (1940): 6.

Felsőmagyarországi Reggeli Hírlap 50, no. 44 (22 February 1941): 5.

Feyer, George. “Olvasói levél.” Irodalmi Újság 11, no. 3 (1965): 8.

“Hamburg - Budapest!" Színházi Élet 7, no. 5 (1922): 22-3.

"Hat intervju A hamburgi menyasszony-ról." Színházi Élet 7, no. 4 (1922): 18-9. Keményfi, Róbert. “Az 'etnikai táj’ kultúrnemzeti mítosza.” Regio 2, no. 4 (2002): 105.

Kötő, József. “A színházi intézményrendszer Erdélyben a két világháború között.” Korunk 13, no. 4 (2002): 55-64.

34 Mária Ormos, "Magyarország az első világháború utáni játéktéren," História 42, no. 11 (1990): 18-21. 
Kulinyi, Ernő, and Zsigmond Vincze. Hamburgi menyasszony. [Libretto prompter's copy]. Translated by M. Jakfalvi. s. 1. n., 1922. Széchényi National Library, Archives.

László, Ferenc. "Rumänische Stilelemente in Bartóks Musik - Fakten und Deutungen." Studia Musicologica Academiae Scientiarum Hungaricae 36, no. 3-4 (1995): 413-28. https://doi.org/10.2307/902223.

Libretto with director's notes. Széchényi National Library, Archives, 136.

Lynch, Kevin. The image of the city. Ann Arbor: MIT, 1960.

Ormos, Mária. “Magyarország az első világháború utáni játéktéren.” História 42, no. 11 (1990): 18-21.

Stachó, László. “Szép vagy, gyönyörű vagy... Magyarország?” Muzsika 49, no. 5 (2006): 33-39.

Tamás, Edit. “A Bodrogköz tájmonográfiája." Zempléni múzsa 9, no. 35 (2009): 87-90.

Uj Budapest, January 18, 1922, 4.

“Új asszony érkezett Hamburgból." Színházi Élet 9, no. 5 (1924): 24. 